\title{
STUDI WILLINGNESS TO PAY PENGGUNA JALAN TERHADAP TARIF TOL SOLO-NGAWI (STUDI KASUS : KARTASURA-NGAWI)
}

\author{
Dewi Handayani ${ }^{1}$, Amirotul MHM², dan Praditya Dwi Kusumananti ${ }^{3}$ \\ ${ }^{1,2}$ Pengajar Jurusan Teknik Sipil,Universitas Negeri Sebelas Maret \\ ${ }^{3}$ Mahasiswa Jurusan Teknik Sipil,Universitas Negeri Sebelas Maret \\ Jl. Ir Sutami 36 A, Kentingan Surakarta 57126; Telp 0271-634524. Fax 662118 \\ Email: kusumananti@gmail.com
}

\begin{abstract}
Solo-Ngawi toll road was constructed to shorten travelling time period. Travel time by main road takes $90,25 \mathrm{~km}$ while $86,4 \mathrm{~km}$ by toll road. Toll road tariff is determined by user willingness to pay. Therefore, the research purpose is to determined the value of user willingness to pay towards Solo-Ngawi toll road tariff. Primary data was obtained by distributing stated preference questionnaire to user that use four-wheel vehicle as their private transportation. Survey form consist of form 1 that contain respondents characteristic and form 2 that contain respondents choice over 2 route options. In form 2, 9 scenarios were provided deriving from 2 attributes : cost and travelling time period. Respondent characteristic is used to analyze WTP, that consist of transportation cost, income, age, occupation and gender. After that, the data obtained will be analyzed using binomial logit and binary probit model. Utility with binomial logit $U_{j t \text {. }}$ ${ }_{j n t}=3,709-0,080\left(C_{j t}-C_{j n t}\right)+0,021\left(T_{j t}-T_{j n t}\right)$ and $U_{j t \text { tjnt }}=2,119-0,046\left(C_{j t}-C_{j n t}\right)+0,012\left(T_{j t}-T_{j n t}\right)$ with binary probit. Highest WTP value is obtained when the cost offered the lowest price in non-toll road with heavy traffic, Rp36.894,46 with binomial logit model and Rp35.854,40 with binary probit model.Category-based WTP shown that only transportation cost per month that are directly proportional with the WTP value spent. Based on occupation category, private employee has the highest WTP value. Respondents in their productive age has the highest WTP value amongst the other group age range. As a whole, male respondent WTP value are higher than female respondent.
\end{abstract}

Keywords: toll road, Willingness To Pay, binomial logit, binary probit, stated preference

\begin{abstract}
Abstrak
Pembangunan jalan tol Solo-Ngawi dilakukan untuk mempersingkat waktu tempuh perjalanan. Jarak perjalanan melalui jalan arteri sepanjang 90,25 km sedangkan melalui jalan tol sepanjang $86,4 \mathrm{~km}$. Penentuan tarif jalan tol disesuaikan dengan kemauan membayar (Willingness To Pay) calon pengguna jalan tol. Oleh karena itu, tujuan penelitian ini adalah untuk mengetahui nilai Willingness To Pay (WTP) pengguna jalan terhadap tarif jalan tol Solo-Ngawi. Penyebaran kuisioner stated preference kepada pengguna kendaraan pribadi roda empat untuk mendapatkan data primer. Formulir survei terdiri dari formulir 1 yang berisi data karakteristik responden serta formulir 2 yang berisi pilihan responden terhadap 2 pilihan rute. Pada formulir 2, disediakan 9 skenario yang diperoleh dari 2 atribut yaitu biaya dan waktu tempuh. Karakteristik responden untuk menganalisis WTP adalah biaya tranportasi, pendapatan, usia, pekerjaan dan jenis kelamin. Data yang diperoleh dianalisa dengan model logit binomial dan probit biner. Utilitas dengan model logit binomial $\mathrm{U}_{\mathrm{jt} \text {-jnt }}=3,709-0,080\left(\mathrm{C}_{\mathrm{jt}}-\mathrm{C}_{\mathrm{jnt}}\right)+0,021\left(\mathrm{~T}_{\mathrm{jt}}-\mathrm{T}_{\mathrm{jnt}}\right)$ dan utilitas dengan model probit biner $\mathrm{U}_{\mathrm{jt}-\mathrm{jnt}}=2,119-0,046\left(\mathrm{C}_{\mathrm{jt}}-\mathrm{C}_{\mathrm{jnt}}\right)+0,012\left(\mathrm{~T}_{\mathrm{jt}}-\mathrm{T}_{\mathrm{jnt}}\right)$. Responden memiliki nilai WTP terbesar saat tarif yang ditawarkan paling rendah dengan keadaan jalan non tol macet, sebesar Rp36.894,46 dengan model logit binomial dan Rp35.854,40 dengan model probit biner. WTP berdasarkan kategori menunjukkan hanya biaya transportasi per bulan yang berbanding lurus dengan nilai WTP. Besar pendapatan responden tidak berbanding lurus dengan WTP yang dikeluarkan. Berdasarkan kategori pekerjaan, responden karyawan swasta memiliki nilai WTP terbesar. Nilai WTP pada responden usia prduktif paling besar diantara rentang usia lain. Secara keseluruhan WTP respoden laki-laki lebih besar dibanding perempuan.
\end{abstract}

Kata kunci: jalan tol, Willingness To Pay, binomial logit, probit biner, stated preference

\section{PENDAHULUAN}

Jalan tol adalah jalan umum yang merupakan bagian sistem jaringan jalan dan sebagai jalan nasional yang penggunaannya diwajibkan membayar tol (UU RI no. 38 tahun 2004). Pembangunan infrastruktur jalan di Pulau Jawa sangat dibutuhkan untuk menunjang mobilitas yang tinggi. Guna memperlancar arus lalu lintas serta meningkatkan hasil pembangunan di dalam pulau jawa maka dibangunlah tol trans jawa. Hal tersebut sejalan dengan kebijakan pemerintah dalam mendukung percepatan pembanguan infrastruktur nasional. Pembangunan mega proyek tol trans jawa, salah satu ruas nya adalah tol Solo-Ngawi. Penelitian ini meninjau segmen Kartasura-Ngawi. Potensi jalan tol Solo-Ngawi untuk dilewati masyarakat cukup besar karena adanya perbedaan waktu tempuh. Hal itu harus diselaraskan dengan kesediaan membayar masyarat terhadap tarif jalan tol. Oleh karena itu, perlu dilakukan penelitian tentang Willingness To Pay untuk mendapatkan nilai dengan dasar kesediaan membayar dari masyarakat melalui data yang didapatkan melalui survei responden. 
Penelitian yang akan dilakukan adalah studi Willingness To Pay pengguna jalan terhadap tarif tol Solo-Ngawi pada segmen Kartasura-Ngawi. Mengambil lokasi penelitian di jalan arteri Solo-Ngawi sesuai dengan segmen tol yang akan diteliti. Penghematan waktu berkisar antara 14 menit sampai 98 menit. Objek penelitian adalah pemilik kendaraan golongan I. Variabel dalam penelitian ini adalah waktu tempuh dan biaya yang dikeluarkan. Pengolahan data digunakan metode stated preference sama seperti penelitian Ryandika (2011) namun perbedaanya responden diberi skenario perjalanan untuk memilih iya atau tidak untuk melewati jalan tol yang mempersingkat waktu tempuh namun mengeluarkan sejumlah biaya. Penelitian Panjaitan (2011) menggunakan 4 variabel untuk mendapat utilitas, sedangkan pada penelitian ini hanya digunkan 2 variabel. Julien (2011) dan Muhammad Rahmad (2012) menggunakan metode household budget dalam pendekatan mencari Willingeness To Pay, sedangkan pada penelitian ini tidak. K. Mahirah (2015) dan Babak Mirbaha (2013) menganilis penelitiannya dengan model logit saja, sedangkan pada penelitian ini analisi WTP menggunakan model logit dan probit. Penelitian ini menggunakan pendekatan NEV (Nett Economic V alue) yang mendukung penelitian oleh Endang Widjajanti (2010). Perbedaan penelitian ini adalah penambahan penggunaan model probit biner untuk mendapat nilai kesediaan masyarakat (Willingeness To Pay) terhadap tarif tol Solo-Ngawi dengan studi kasus segmen Kartasura-Ngawi.

\section{TINJAUAN PUSTAKA DAN LANDASAN TEORI}

\section{Jalan Tol}

Jalan tol adalah jalan umum yang merupakan bagian system jaringan jalan dan sebagai jalan nasional yang penggunaanya diwajibkan membayar tol. Sedangkan tol sendiri adalah sejumlah uang tertentu yang dibayarkan untuk pengguanaan jalan tol (UU RI no.38 tahun 2004).

\section{Willingness to Pay (WTP)}

Willingness To Pay adalah kesediaan pengguna untuk mengeluarkan biaya atas jasa yang didapatnya (Christoph Breidert, 2006). Analisis W'TP dilakukan dengan pendekatan NEV (Nett Economic V alue), yang dapat dilihat pada persamaan (1).

$$
\begin{aligned}
& \text { WTP } \approx N E V \\
& \text { NEV }=P(x) \times \frac{x}{d}
\end{aligned}
$$

dengan $P(x)=$ Probabilitas responden untuk harga $X(\mathrm{Rp}) ; x=$ harga tol yang ditawarkan $(\mathrm{Rp})$ dan $d=$ jarak tempuh.

\section{Metode Stated Preference}

Stated preference adalah sebuah pendekatan dengan menyampaikan pernyataan pilihan berupa suatu hipotesa untuk dinilai oleh responden. Dengan menggunakan teknik stated preference, peneliti dapat mengontrol secara penuh faktor yang ada pada skenario yang dihipotesis (Rendy,2011).

\section{Model Logit Binomial}

Pennelitian ini menggunakan model logit binomial untuk menghitung analisis probabilitas. Rumus probabilitas model logit binomial dapat dilihat pada Persamaan (2) (Ortuzar dan Willumsen, 2001).

$$
P_{j t}=\frac{1}{1+e^{-\mu \beta\left(U_{j t}-U_{j n t}\right)}}
$$

dengan $\mathrm{P}_{\mathrm{jt}}=$ probabilitas pemilihan jalan tol; $\beta=$ parameter kalibrasi; $\mathrm{U}_{\mathrm{jt}}=$ utilitas pemilihan jalan tol dan $\mathrm{U}_{\mathrm{jnt}}=\mathrm{utilitas}$ pemilihan jalan non tol.

\section{Model Probit Biner}

Penelitian ini juga menganalisis probabilitas menggunakan jalan tol dengan model probit biner berdasarkan persamaan yang dapat dilihat pada Persamaan (3) (Ortuzar dan Willumsen, 2001).

$$
P_{\mathrm{jt}}=\varphi\left(\frac{U_{j t}-U_{j n t}}{\sigma}\right)
$$

dengan $\mathrm{P}_{\mathrm{jt}}=$ probabilitas pemilihan jalan tol; $\varphi=$ kumulatif distribusi normal; $\sigma=$ standar deviasi; $\mathrm{U}_{\mathrm{jt}}=$ utilitas pemilihan jalan tol dan $\mathrm{U}_{\text {jnt }}=$ utilitas pemilihan jalan non tol. 


\section{Uji Statistik}

Uji statistik pada penelitian ini meliputi uji koefisien determinasi, chi-square dan overall percentage. Tamim (2000), koefisien determinasi didefinisikan sebagai nisbah antara variasi tidak terdefinisi dengan variasi total. Pengujian Pengujian overall percentage dilakukan untuk melihat apakah seluruh koefisien regresi dan variabel bebas yang ada dalam model regresi linear berganda berbeda dari nol atau nilai konstanta tertentu (Miro,2005).

\section{METODE PENELITIAN}

Lokasi penelitian ini dilakukan jalan arteri Solo-Ngawi kepada para pengguna jalan. Dipilihnya ruas jalan tersebut untuk merepresentasikan kesediaan membayar (Willingness To Pay) masyarakat yang berpotensi akan menggunakan ruas tol ketika sudah dioperasikan. Jalan tol Solo-Ngawi ini membentang sepanjang 90,25 km dari Kartasura hingga Ngawi yang terletak di 5 Kabupaten dan 2 Provinsi yaitu Boyolali, Surakarta, Karanganyar, Sragen (Provinsi Jawa Tengah) dan Kabupaten Ngawi (Provinsi Jawa Timur). Data responden diperoleh dari penyebaran kuisioner melalui wawancara langsung. Analisis data dilakukan dengan bantuan Microsoft Excel dan SPSS 17.0

Tahapan penelitian yang pertama dilakukan adalah uji data responden yang diperoleh. Setelah itu data responden di olah dengan bantuan SPSS 17.0 untuk mendapat utilitasnya. Setelah utilitas diketahui dilakukan uji statistik untuk menguji kelayakan utilitas. Utilitas yang sesuai dengan kelayakan uji statitistik digunkan untuk mendapat probabilitas. Setelah diketahui probabilitas, nilai WTP dapat diketahui sesuai dengan pendekatan Nett Economic Value. Tahapan yang sama dilakukan untuk mendapat nilai WTP berdasarkan karakteristik responden.

\section{HASIL DAN PEMBAHASAN}

\section{Analisis Pemilihan Rute Jalan Tol Model Logit Binomial}

Dari hasil pengujian logit binomial dengan bantuan SPSS 17.0, didapatkan model utilitas sebagai berikut :

$\mathrm{U}_{\mathrm{jt}-\mathrm{jnt}}=3,709-0,080\left(\mathrm{C}_{\mathrm{jt}}-\mathrm{C}_{\mathrm{jnt}}\right)+0,021\left(\mathrm{~T}_{\mathrm{jt}}-\mathrm{T}_{\mathrm{jnt}}\right)$

Semakin besar tarif yang dikeluarkan maka nilai utilitas akan semakin kecil, sedangkan semakin besar perbedaan waktu maka utilitas akan semakin besar pula. Utilitas tersebut diuji statistik. Hasil uji R-Square sebesar 0,58, uji Chi-Square sebesar 50,85 dan hasil Overall Precentage sebesar 76\%. Semua hasil uji menyatakan utilitas layak digunakan karena sesuai sengan syarat statistik. Probabilitas pemilihan rute dapat dihitung sebagai berikut :

$$
P_{j t-j n t}=\frac{1}{1+\exp ^{-\left(3,709-0,080\left(C_{j t}-C_{j n t}\right)+0,021\left(T_{j t}-T_{j n t}\right)\right)}}
$$

\section{Analisis Pemilihan Rute Jalan Tol Model Probit Biner}

Dari hasil pengujian probit biner, didapatkan model utilitas sebagai berikut :

$\mathrm{U}_{\mathrm{jt}-\mathrm{jnt}}=2,119-0,046\left(\mathrm{C}_{\mathrm{jt}}-\mathrm{C}_{\mathrm{jnt}}\right)+0,012\left(\mathrm{~T}_{\mathrm{jt}}-\mathrm{T}_{\mathrm{jnt}}\right)$

Utilitas tersebut diuji statistik. Hasil uji R-Square sebesar 0,57, uji Chi-Square sebesar 63,01 dan hasil Overall Precentage sebesar $75,9 \%$. Semua hasil uji menyatakan utilitas layak digunakan karena sesua sengan syarat statistik. Probabilitas pemilihan rute dapat dihitung sebagai berikut :

$$
\mathrm{P}_{\mathrm{jt}-\mathrm{jnt}}=\varphi\left(\frac{2,119-0,046\left(\mathrm{C}_{\mathrm{jt}}-C_{j n t}\right)+0,012\left(\mathrm{~T}_{\mathrm{jt}}-T_{j n t}\right)}{\sigma}\right)
$$

\section{Analisis Willingness To Pay dengan Logit Binomial}

Berdasarkan persamaan probabilitas pemilihan jalan tol akan didapat nilai Willingness To Pay dari responden. Semakin besar Perhitungan nilai Willingness To Pay pengguna jalan terhadap jalan tol Solo-Ngawi dapat dilihat pada tabel 1. 


\begin{tabular}{|c|c|c|c|c|c|c|c|c|}
\hline Skenario & $\begin{array}{c}\text { Jarak } \\
(\mathrm{d}) \\
(\mathrm{km})\end{array}$ & $\begin{array}{l}\text { Tarif Tol } \\
(\mathrm{x})(\mathrm{Rp})\end{array}$ & $\begin{array}{l}\text { Waktu } \\
\text { (Menit) }\end{array}$ & Utilitas & $\begin{array}{c}\text { Probabilitas } \\
\text { (P) }\end{array}$ & $\begin{array}{c}\text { WTP } \\
([\mathrm{p} \cdot \mathrm{x}] / \mathrm{d})\end{array}$ & $\begin{array}{c}\text { WTP } \\
(\mathrm{Rp} / \mathrm{km})\end{array}$ & WTP (Rp) \\
\hline 1 & \multirow{9}{*}{86,4} & $52.000,00$ & 14 & $-0,157$ & 0,461 & 0,277 & 277,352 & $23.963,182$ \\
\hline 2 & & $73.500,00$ & 35 & $-1,436$ & 0,192 & 0,116 & 115,655 & $9.992,608$ \\
\hline 3 & & $95.000,00$ & 48 & $-2,883$ & 0,053 & 0,032 & 31,898 & $2.756,019$ \\
\hline 4 & & $52.000,00$ & 39 & 0,368 & 0,591 & 0,356 & 355,680 & $30.730,732$ \\
\hline 5 & & $73.500,00$ & 60 & $-0,911$ & 0,287 & 0,173 & 172,608 & $14.913,353$ \\
\hline 6 & & $95.000,00$ & 73 & $-2,358$ & 0,086 & 0,052 & 52,019 & $4.494,463$ \\
\hline 7 & & $52.000,00$ & 64 & 0,893 & 0,710 & 0,427 & 427,019 & $36.894,462$ \\
\hline \multirow{2}{*}{$\begin{array}{l}8 \\
9\end{array}$} & & $73.500,00$ & 85 & $-0,386$ & 0,405 & 0,244 & 243,558 & $21.043,391$ \\
\hline & & $95.000,00$ & 98 & $-1,833$ & 0,138 & 0,083 & 82,984 & $7.169,826$ \\
\hline \multicolumn{7}{|c|}{ WTP Rata-Rata } & 195,419 & $16.884,226$ \\
\hline
\end{tabular}

Tabel 1. Perhitungan Nilai WTP Jalan Tol Solo-Ngawi dengan Logit Binomial

\section{Analisis Willingness To Pay dengan Probit Biner}

Berdasarkan persamaan probabilitas pemilihan jalan tol akan didapat nilai Willingness To Pay dari responden. Perhitungan nilai Willingness To Pay pengguna jalan terhadap jalan tol Solo-Ngawi dapat dilihat pada tabel 2.

Tabel 2. Perhitungan Nilai WTP Jalan Tol Solo-Ngawi dengan Probit Biner

\begin{tabular}{|c|c|c|c|c|c|c|c|c|}
\hline Skenario & $\begin{array}{c}\text { Jarak } \\
(\mathrm{d}) \\
(\mathrm{km})\end{array}$ & $\begin{array}{c}\text { Tarif } \\
\text { Tol (x) } \\
\text { (Rp) }\end{array}$ & $\begin{array}{l}\text { Waktu } \\
\text { (Menit) }\end{array}$ & Pembilang & $\begin{array}{c}\text { Probabilitas } \\
\text { (P) }\end{array}$ & $\begin{array}{c}\text { WTP } \\
([\mathrm{p} \cdot \mathrm{x}] / \mathrm{d})\end{array}$ & $\begin{array}{c}\text { WTP } \\
(\mathrm{Rp} / \mathrm{km})\end{array}$ & $\begin{array}{l}\text { WTP } \\
\text { (Rp) }\end{array}$ \\
\hline 1 & & $52.000,00$ & 14 & $-0,105$ & 0,458 & 0,276 & 275,761 & $23.825,77$ \\
\hline 2 & & $73.500,00$ & 35 & $-0,842$ & 0,200 & 0,170 & 170,049 & $14.692,21$ \\
\hline 3 & & $95.000,00$ & 48 & $-1,675$ & 0,047 & 0,052 & 51,642 & $4.461,88$ \\
\hline 4 & & $52.000,00$ & 39 & 0,195 & 0,577 & 0,347 & 347,451 & $30.019,78$ \\
\hline 5 & 86,4 & $73.500,00$ & 60 & $-0,542$ & 0,294 & 0,250 & 250,027 & $21.602,33$ \\
\hline 6 & & $95.000,00$ & 73 & $-1,375$ & 0,085 & 0,093 & 92,983 & $8.033,74$ \\
\hline 7 & & $52.000,00$ & 64 & 0,495 & 0,690 & 0,415 & 415,097 & $35.864,40$ \\
\hline 8 & & $73.500,00$ & 85 & $-0,242$ & 0,404 & 0,344 & 344,012 & $29.722,67$ \\
\hline 9 & & $95.000,00$ & 98 & $-1,075$ & 0,141 & 0,155 & 155,241 & $13.412,80$ \\
\hline \multicolumn{7}{|c|}{ WTP Rata-Rata } & 233,585 & $20.181,73$ \\
\hline
\end{tabular}

\section{Perbandingan Willingness To Pay Logit Binomial dengan Probit Biner}

Perbandingan kedua nilai WTP disajikan dalam bentuk grafik pada gambar 1 dan 2 berikut

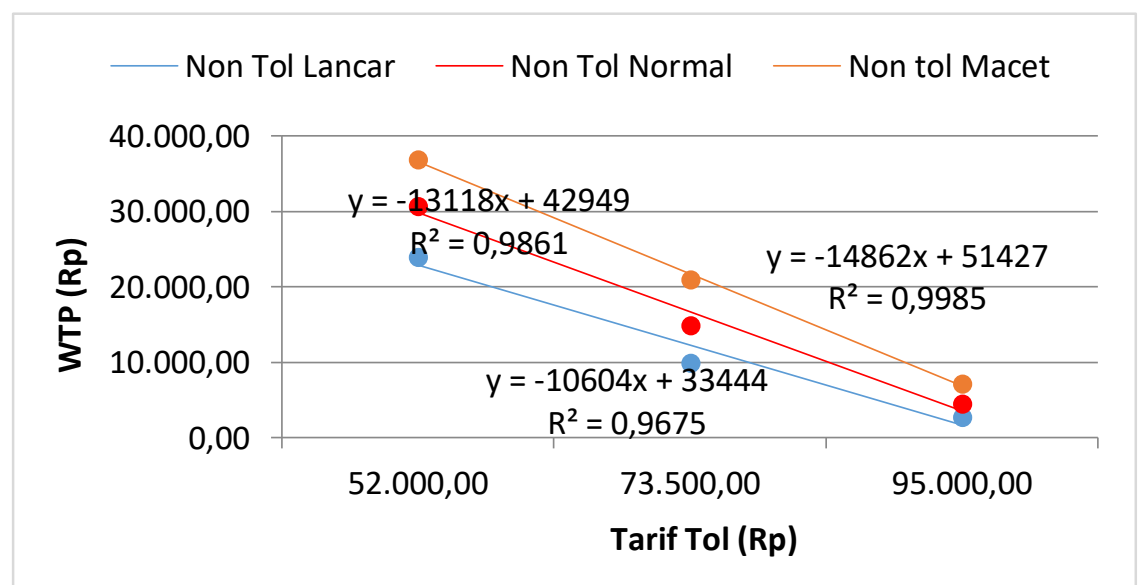




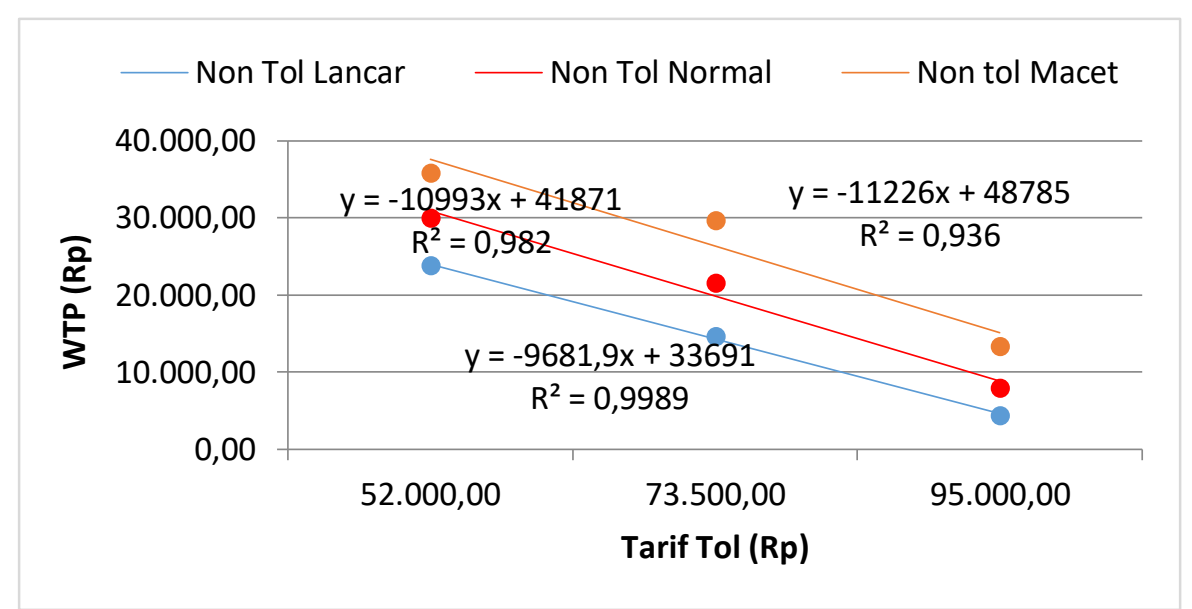

Gambar 2. Willingness To Pay dengan Probit Biner

Gambar 1 menunjukkan WTP yang akan dikeluarkan responden jika diberikan skenario saat keadaan non tol lancar, normal dan macet. Terlihat bahwa pada keadaan non tol macet nilai W'TP responden paling besar. Responden akan memilih melewati jalan tol jika jalan non tol macet. Variabel selisih waktu tempuh mempengaruhi pilihan responden untuk melewati jalan tol. Pada keadaan jalan non tol lancar WTP responden untuk memilih melewati jalan tol paling kecil. Responden cenderung tidak melewati jalan tol saat jalan non tol lancar. Hal itu dikarenakan sedikitnya perbedaan waktu tempuh. Responden juga tidak perlu mengeluarkan biaya lebih jika melewati jalan non tol. Karakteristik yang sama juga ditunjukkan oleh WTP dengan probit biner yang dapat dilihat pada Gambar 2.

\section{Analisis Willingness To Pay Berdasarkan Karaktersitik Responden}

Analsisis hasil pengolahan data mengenai WTP berdasarkan karakteristik responden antara lain :

a. Biaya Transportasi

WTP berdasarkan biaya transportasi disajikan pada Gambar 3 berikut

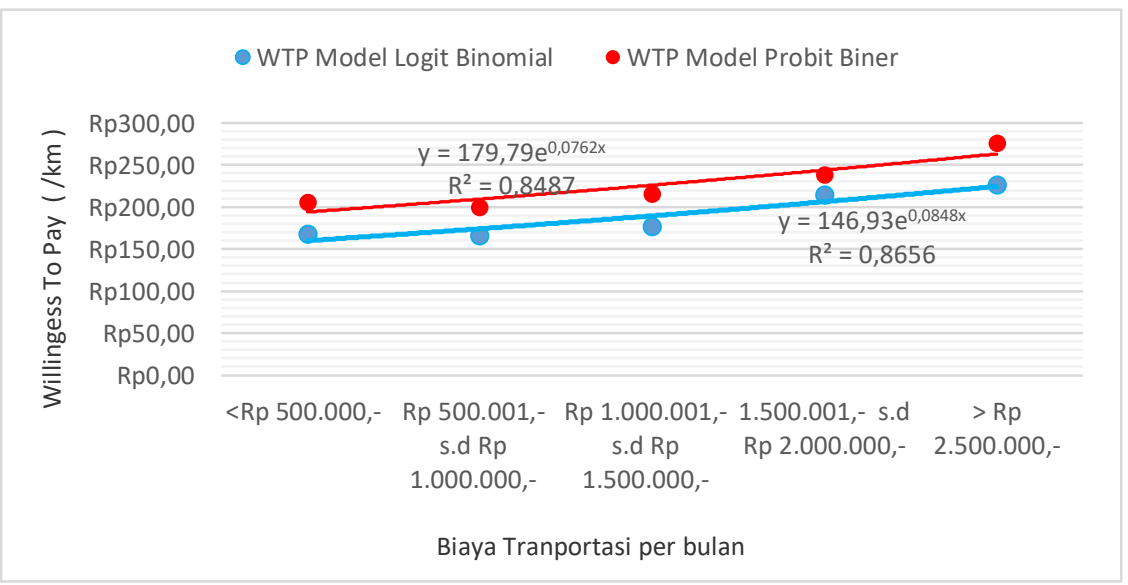

Gambar 3. Willingness To Pay Berdasarkan Biaya Transportasi

Dari Gambar 3, secara keseluruhan WTP berbanding lurus dengan biaya transportasi yang dikeluarkan responden per bulannya. WTP terkecil ada pada rentang kurang dari Rp500.000,- dan terbesar pada rentang diatas Rp2.500.000,- per bulan. Dari hasil tersebut dapat dikatakan bahwa biaya transportasi per bulan mempengaruhi besar WTP dari responden. Dengan koefisien determinasi 0,86 dari model logit binomial, artinya biaya transportasi per bulan mempengaruhi WTP sebanyak 86\%. Maka besarnya WTP berdasarkan biaya transportasi dapat digunakan untuk menunjukkan WTP dari responden. 
b. Pendapatan

Willingness To Pay berdasarkan gaji pokok per bulan dapat dilihat pada Gambar 4.

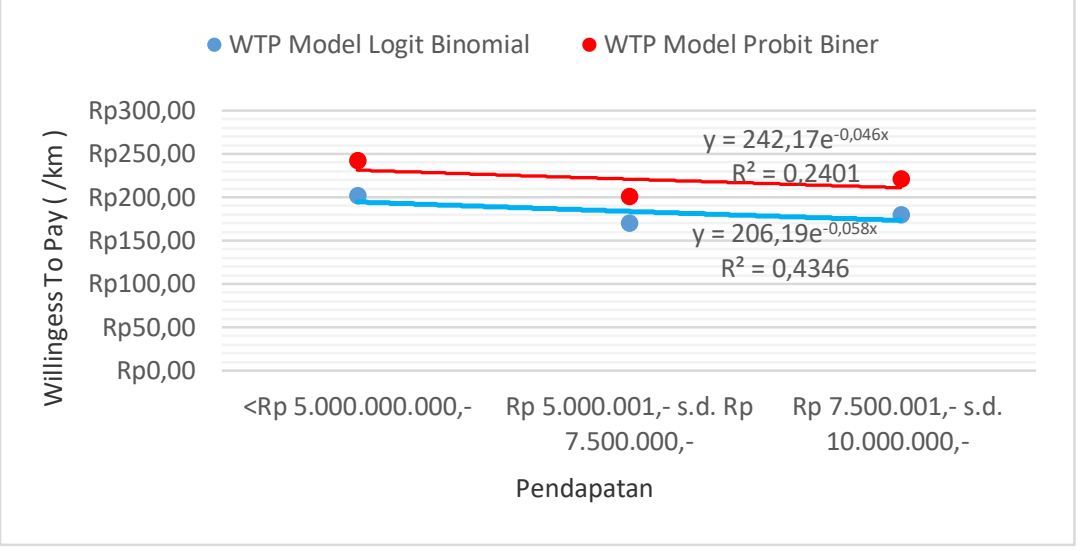

Gambar 4. Willingness To Pay Berdasarkan Pendapatan

Berdasarkan Gambar 4, pendapatan dibawah Rp5.000.000 memiliki nilai W'TP terbesar. Dengan model logit binomial didapat sebesar Rp201,168/km dan dengan model probit biner didapat sebesar Rp 242,468/km. WTP terbesar ada pada responden dengan rentang pendapatan paling kecil. Koefisien determinasi dari kedua model sebesar 0,43 dari model logit binomial dan 0,24 dari model probit biner. Dilihat dari koefien determinasi, WTP berdasarkan pendapatan tidak memiliki trendline tertentu, sehingga pendapatan tidak menunjukkan pengaruh signifikan terhadap WTP responden. Tingginya pendapatan responden tidak berbanding lurus dengan W'TP.

c. Usia

W'TP berdasarkan usia dapat dilihat pada Gambar 5 berikut

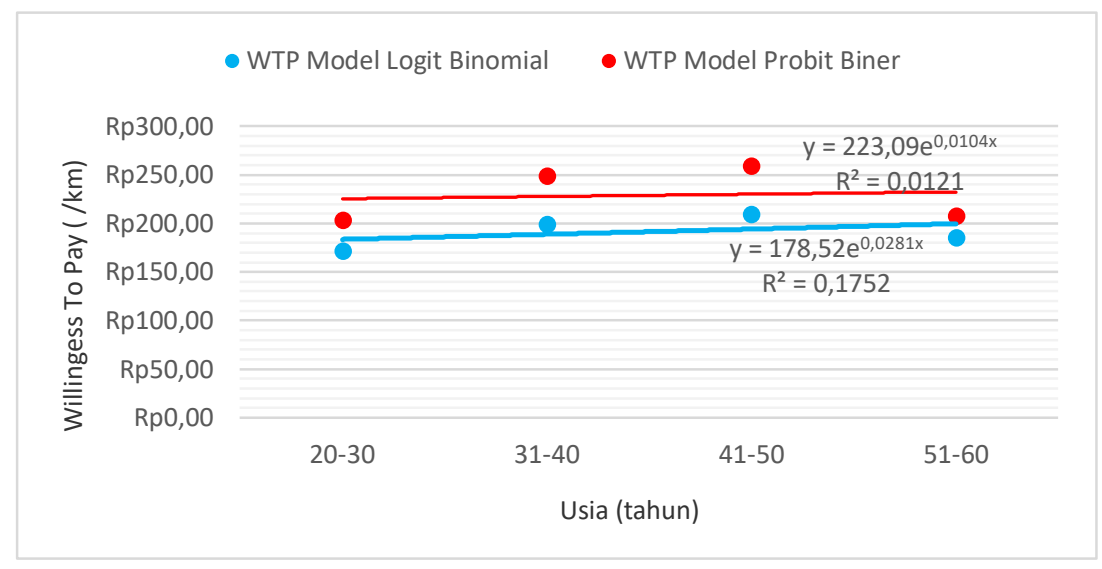

Gambar 5. Willingness To Pay Berdasarkan Usia

WTP terbesar ada pada rentang 41-50 tahun. Rp210,186/km dengan model logit binomial dan Rp259,313/km dengan model probit biner. Nilai WTP terbesar kedua adalah pada rentang usia 31-40 tahun sebesar Rp199,725/km dengan model logit binomial dan Rp248,985/km dengan model probit biner. Rentang usia 31-50 tahun merupakan rentang usia produktif. Hasil dari analisis menunjukkan WTP terbesar ada pada responden dengan usia produktif. Hal itu cukup masuk akal karena responden usia produktif memiliki mobilitas lebih besar dibanding rentang usia lain. Sehingga kecenderungan untuk membayar lebih akan dilakukan oleh responden pada usia produktif. 
d. Pekerjaan

WTP berdasarkan jenis pekerjaan dapat dilihat pada Gambar 6. WTP tertinggi adalah responden dengan pekerjaan karyawan swasta sebesar Rp 220,978/km dengan model logit binomial, dan Rp 260,981/km dengan model probit biner.

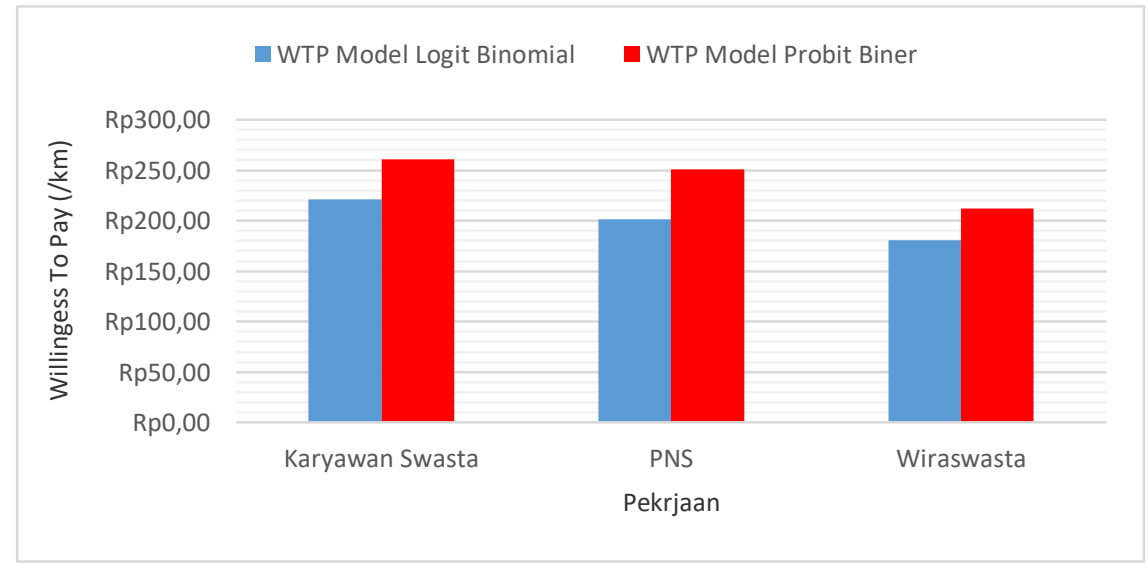

Gambar 6. Willingness To Pay Berdasarkan Pekerjaan

Gambar 6 menunjukkan jenis pekerjaan tidak berpengaruh signifikan terhadap WTP. Pekerjaan responden tidak dapat menunjukkan keterkaitan dengan WTP karena data yang didapat terlalu beragam.

e. Jenis Kelamin

WTP berdasarkan jenis kelamin disajikan pada Gambar 7 berikut

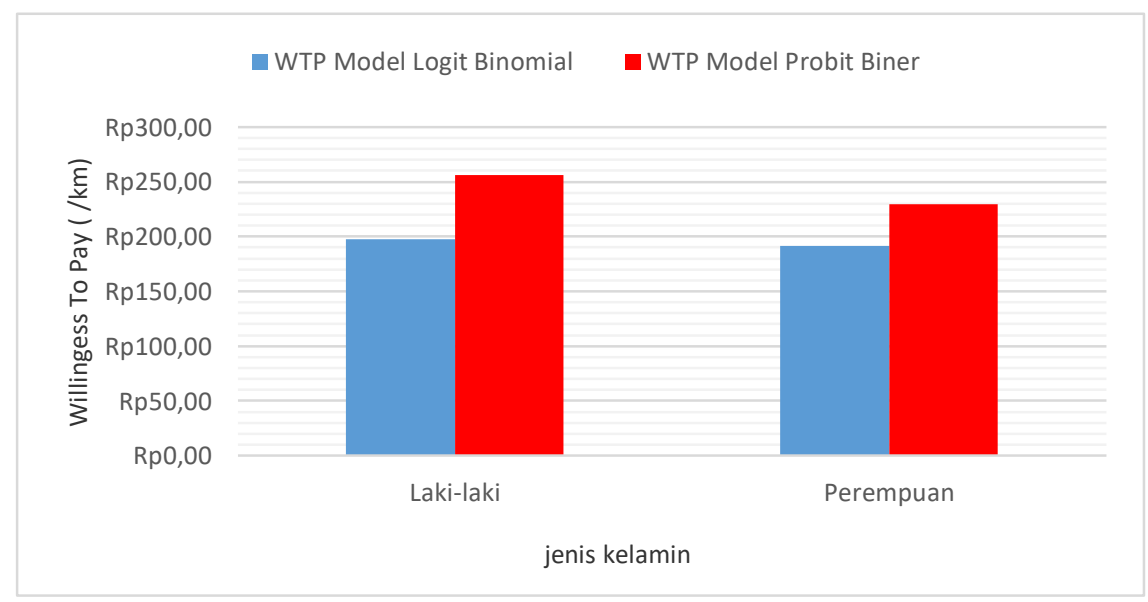

Gambar 7. Willingness To Pay Berdasarkan Jenis Kelamin

Berdasarkan Gambar 7, responden pria menunjukkan nilai WTP lebih besar dibanding responden perempuan. Hal tersebut menunjukkan bahwa responden pria memiliki kemauan untuk membayar lebih untuk melewati jalan tol. WTP responden pria sebesar Rp197,586/km, dan responden perempuan Rp191,395/km dari model logit binomial. Sama seperti jenis pekerjaan, WTP berdasarkan jenis kelamin responden tidak dapat menunjukkan trend tertentu.

Hasil penelitian ini mendukung penelitian Endang Widjajanti (2010), yang mendapatkan nilai WTP dengan pendekatan Nett Economic Value. Penelitian Julien (2011) mengatakan variabel biaya dan waktu tempuh mempengaruhi nilai WTP responden, hal ini mendukung hasil penelitian yang telah dilakukan. 


\section{KESIMPULAN}

Berdasarkan hasil penelitian dan pembahasan, maka dapat disimpulkan beberapa hal sebagai berikut:

a. Berdasarkan hasil penelitian yang telah dilakukan, responden memiliki nilai Willingness To Pay (WTP) terbesar saat tarif yang ditawarkan paling rendah dengan keadaan jalan non tol macet, sebesar Rp36.894,46 dengan model logit binomial dan Rp35.854,40 dengan model probit biner.

b. WTP berdasarkan kategori menunjukkan hanya biaya transportasi per bulan yang berbanding lurus dengan nilai WTP. Besar pendapatan responden tidak berbanding lurus dengan WTP yang dikeluarkan. Berdasarkan kategori pekerjaan, responden karyawan swasta memiliki nilai WTP terbesar. Nilai WTP pada responden usia prduktif paling besar diantara rentang usia lain. Secara keseluruhan WTP respoden laki-laki lebih besar dibanding perempuan.

\section{REFERENSI}

Breidert, Christoph.2006. A Review Of Method For Measuring Willingness To Pay. Austria.

Hanri, Muhammad.2009.Sistem Peringatan Dini Krisis Nilai Tukar : Kasus Indonesia Tabun 1990 - 2008. Depok :Jurnal Universitas Indonesia.

Hensher, David A.1993. Stated Preference Analysis Of Travel Choice: The State Of Practice. Netherland.

Jarak antar kota Kartasura - Ngawi, 2017. http://jarakantarkota.com/.

Diakses pada tanggal 6 April 2017.

Julien.2011. Analisis Ability To Pay dan Willingness To Pay Pengguna Jasa Kereta Api Bandara Kualanamu..Medan : Jurnal Universitas Sumatera Utara.

Kroes, Eric P. dan Robert J Sheldon.1988. Stated Preference Methods : An Introduction.Journal Of Transport Econimics and Policy.

Mahirah, K. 2015. Valuing Road User's Willingness To Pay to Reduce Traffric Congestion in Klang V alley, Malaysia. Kuala Trengganu, Malaysia.

Mirbaha, Babak. 2013. Evalaluating the Willingness To Pay for Urban Congestion Priced Zones (Case Study Of Tehran). Teheran, Iran.

Miro, Fidel. 2005. Perencanaan Transportasi. Jakarta: Erlangga.

Ortuzar, J.D. and Willumsen, L.G. (1994) "Modelling Transport", Third Edition, Jhon Wiley \& Sons

Panjaitan, Imelda Monalisa. 2012. Pemodelan Pemiliban Moda Angkutan Penumpang Karya Agung dan KBT (Koperasi Bintang Tapanuli ) dengan Ketepatan Model Probit dan Logit Studi Kasus (Medan-Baligae). USU Medan.

Panjaitan, Indra Ferdinan. 2011. Analisa TarifJalan Tol Berdasarkan Pendekatan Willingness To Pay (WTP) dan Ability To Pay (ATP) Studi Kasus : Rancana Jalan Tol Medan - Binjai. USU Medan.

Parikesit, Danang.1993.Kemungkinan Penggunaan Teknik. Stated Preference dalam Perencanaan Angkutan Umum.Forum Teknik Sipil No II/I - Agustus 1993. UGM Yogyakarta.

Pengelola Jalan Tol PT. Solo Ngawi Jaya, 2017. http://solongawijaya.com/link. Diakses pada tanggal 8 Maret 2017.

Permata, Muhammad Rahmad. Analisa Ability To Pay dan Willingness To Pay Pengguna Jasa Kereta Api Bandara Soekarno Hatta Manggarai. Depok : Jurnal Universitas Indonesia.

PP nomor 67 tahun 2005 tentang Kerjasama Pemerintah dengan Badan Usaha dalam Penyediaan Infrastruktur

Prakoso, Rendy Wisnu.2011. Analisis Taraif Tol Dengan Metode Stated Preference Studi Kasus Jalan Tol JORR II Segmen Cengkareng Kunciran. Depok: Jurnal Universitas Indonesia.

Purba, Herlyn Melisa.2017. Pemiliban Moda Angkutan Kereta Api Kalijaga dan Bus Jurusan Solo-Semarang. Surakarta : Universitas Sebelas Maret.

Rahina, Putri Satya.2015. Nilai Waktu Perjalanan Penumpang Bus Patas Solo-Semarang. Surakarta : Jurnal Universitas Sebelas Maret. Ryandika.2011. Analisis Taraif Tol Dengan Metode Stated Preference Studi Kasus Jalan Tol JORR II Segmen Serpong - Cinere. Depok: Jurnal Universitas Indonesia.

Sugiyono .2011. Metode Penelitian Kuantitatif Kualitatif dan R\&DD. Bandung: Alfabeta.

Tarmin, O.Z.2000. Perencanaan dan Pemodelan Transportasi Jilid 1. ITB. Bandung

Undang - Undang nomor 38 tahun 2004 tentang Jaringan Jalan.

Widjajanti, Endang.2010.Sistem Studi Willingness To Pay (WTP) dan Ability To Pay (ATP) Ruas Jalan Tol di Luar Pulau Jawa. Jakarta : Jurnal Institut Sains dan Teknologi Indonesia. 
